\title{
8 Were children's rights ever a feminist project?
}

\author{
Linde Lindkvist
}

\section{Introduction}

International norm-making on women's rights and children's rights is often historicized as parts of a broader process of challenging the abstract vision of humanity that undergirds mainstream human rights discourse after the Universal Declaration of Human Rights. But women's rights and children's rights have distinct historical trajectories in international human rights politics, and their relationship has not always been free of friction. In 1992, the feminist legal scholar Frances Olsen attempted to make sense of this relationship in commentary on what was then the recently adopted United Nations Convention on the Rights of the Child (1989). Olsen noted how children's rights and women's rights were frequently discussed together in international human rights settings. More specifically, she addressed how women and children often appeared on the same lists of particularly vulnerable groups, and how they were frequently pulled together in provisions on the rights of maternity leave and maternity protection. ${ }^{1}$ Olsen further argued that women's and children's rights are often mutually reinforcing in practice. In other words, where children's rights enjoy a high degree of protection, women tend to fare better too. At the same time, she suggested that international norms on children's rights often perpetuate age-old notions and stereotypes of motherhood, and how the abstract category of "the child" obscures the ways in which the structures of gender work unequally on boys and girls. ${ }^{2}$ Children's rights thus seemed to reinforce the very same essentialist and conservative tendencies in human rights discourse that women's rights activists were trying to counteract.

Considering Olsen's work today raises the difficult question of how the history of children's rights relates to the history of women's rights for the UN. If these concepts are so closely intertwined but at the same time in a state of friction, then how are we to understand their historical relationship? This chapter approaches this question from within the UN's history of children's rights. In examining how children's rights evolved as a subfield of international human rights law and politics, it seeks to capture the contours of this history with an eye on the concept's relation to the ideas of women's rights and gender equality. ${ }^{3}$

Most international histories of children's rights have been set in the aftermath of World War I and have centered on the contributions of humanitarian entrepreneurs like Eglantyne Jebb of the Save the Children Fund. Their charity-based activism was sometimes mocked by radicals who claimed that it "reinforced the 
age-old notion that women had no concern in public life except to wipe up the mess made by men." However, it is now evident that interwar humanitarianism also functioned as a forcefield in which women could advance bold ideas for the enhancement of peace, justice, and civilization. Such ideas frequently revolved around the concept of childhood and, more specifically, the conviction that improved child protection in the present would help to bring about better versions of humankind in generations to come. This line of thought influenced the Geneva Declaration of the Rights of the Child, which originated in the Save the Children Fund and the International Women's Council in the early 1920s and was endorsed by the League of Nations Council in the fall of 1924. This short, five-paragraph manifesto on the essential goods that humankind owes to all children, regardless of race or national boundaries, received widespread circulation in its time and still serves as a source of inspiration for child rights activists. ${ }^{5}$

In 1959, the United Nations adopted its own updated version of the Declaration of the Rights of the Child. Three decades later, this was followed by the UN Convention on the Rights of the Child, which has since become the most ratified international treaty on human rights. The few histories charting the emergence of these later documents have so far paid little attention to the connection between children's rights and women's rights that is so prominent in the historiography of the $1920 \mathrm{~s}^{6}{ }^{6}$ This may partly reflect how the later UN processes were controlled mainly by states, allowing limited space for individual agency. There is, in short, no heroine to which the Convention can be accredited. Still, it is puzzling why the literature on international children's rights has thus far shown little concern for the contributions of women diplomats and activists and has offered almost no analysis of the relationship between children's rights and women's rights. This is all the more surprising given that the talks on the UN Convention on the Rights of the Child coincided with the UN Decade for Women (1975-1985) and the finalization of the Convention on the Elimination of All Forms of Discrimination against Women (1979). Is this just another instance of wiping out the traces of women and non-Western agency in UN treaty-making processes? Or is it indicative of a deeper skepticism among feminists towards the very concept of children's rights?

This chapter offers some observations on how and to what extent women diplomats and activists, and, more broadly, ideas of gender equality, helped to shape the norms on children's rights advanced by the UN between 1945 and the mid1990s. More broadly, it seeks to determine whether it is justifiable to speak of international children's rights as a feminist project, or whether it is more accurate to see children's rights as clashing with projects of gender equality and women's liberation. The conclusion suggests that both of these assessments are true. On the one hand, women representatives repeatedly found ways to use the frameworks on children's rights to advance gender-sensitive conceptions of human rights and to challenge the private-public distinction in international human rights law. At the same time, the main UN instruments on children's rights upheld traditional understandings of the nuclear family as the fundamental social unit and the most conducive realm for promoting children's physical and mental development. 
In doing so, the ways in which gender inequalities play into the lives of young human beings were disregarded. When approaching a document like the UN Convention on the Rights of the Child, we have to bear in mind that it did not resolve such tensions. Rather, the treaty itself contained fundamentally different views on the content and function of children's human rights, lending itself to multiple social and political uses.

\section{From human rights to children's rights}

If historians generally look to the late 1940s as a founding moment of the discourse on universal human rights, child rights scholars view it as an opportunity lost. In 1950, after much lobbying by the Save the Children movement, the UN's Social Commission issued resolution endorsing the fundamental principles of Geneva Declaration, while at the same time suggesting that if there ever would be a UN version of the declaration, it would first have to go through a state-led process of redrafting. ${ }^{7}$ Nevertheless, in spite of some initial discussion, this process soon sputtered to a halt.

One reason for the lack of interest in a child rights instrument was the discourse of human rights. The decision of the newly established UN Commission of Human Rights to devote its energy to the creation of an international bill on the rights of individuals meant that the rights of particular groups-whether distinguished by age, race, gender, or nationality - acquired only limited attention. Still, the text of the Universal Declaration of Human Rights (UDHR) contained some clauses of direct relevance to children, including the right to education and an adequate standard of living. More directly, Article 25(2) announced that "motherhood and childhood are entitled to special care and assistance," further stating that "all children, whether born in or out of wedlock, shall enjoy the same social protection."

Like all the individual passages that comprise the UDHR, Article 25(2) was the product of intense negotiation. The Danish delegate Bodil Begtrup insisted that the term "motherhood" was preferable to a previous proposal that spoke of the rights of "mothers," arguing that this would cover the rights of women both during and after pregnancy. ${ }^{9}$ The word "childhood" was principally chosen for linguistic consistency, even though the Soviet delegate Alexei Pavlov grumbled that motherhood and childhood were, strictly speaking, "abstract ideas" rather than "legal entities" capable of holding rights. ${ }^{10}$ The second part of Article 25(2) betrayed a more substantial disagreement on the status of children born out of wedlock. During the meetings of the General Assembly in the fall of 1948, Ratko Pleic of Yugoslavia - supported by, among others, Minerva Bernardino of the Dominican Republic - insisted that addressing discrimination on the basis of illegitimacy was paramount in an instrument that purported to advance universal rights. ${ }^{11}$ The proposal was attacked by other delegates, such as Marga Klompé of the Netherlands, who feared that it might undermine "the importance of the marriage bond and (...) the principle that the family was the fundamental group unit of society." 12 The reference to the equal rights of social security that ended up in the final version of Article 25(2) was a compromise, acknowledging that 
"illegitimate children" were entitled to social welfare while stopping short of recognizing them as subjects of civil rights, most notably that of inheritance. ${ }^{13}$

The most striking feature of this part of the Universal Declaration, however, is the way it constituted children and women (in the capacity of mothers) as similarly vulnerable objects of benevolence and protection, but at the same time as ideas rather than persons. ${ }^{14}$ As Jessica Whyte has recently shown, the UDHR's language on social and economic rights restated a Fordist idea of the family wage, i.e., the idea that the male head of household should be able to earn enough to provide for the needs of other members of his family. From this perspective, the language on motherhood and childhood mainly functioned as a stop-gap clause in covering the purportedly exceptional situation where a man is either absent or otherwise unable to fulfil his responsibilities. ${ }^{15}$

In spite of the Universal Declaration's limited social vision, the women delegates and activists of the Commission on the Status of Women (CSW) found ways of employing it as a "major tool to combat laws that discriminated against women." ${ }^{16}$ At the same time as the UN Commission on Human Rights struggled to make headway on the general human rights treaty that was meant to follow the non-binding human rights declaration, the CSW used the 1950s to successfully push for new international standards on women's human rights. The most prominent example of such efforts was arguably the 1952 Convention on the Political Rights of Women. However, as Rebecca Adami and Roland Burke show in their contributions to this volume, this work also involved projects that were of direct relevance to children and adolescents. For instance, in 1954, the General Assembly adopted a declaration denouncing traditional customs and practices, including bride price and child marriage, which later influenced the 1962 Convention on Consent to Marriage, Minimum Age for Marriage and Registration of Marriages. ${ }^{17}$ In the same period, the CSW took on questions of gender equality in access to education and joined forces with the International Labour Organization and the World Health Organization to advance social and economic rights for working mothers, such as access to daycare and child care after school hours. ${ }^{18}$

What often united these efforts was a strong sense of pragmatism. Focusing more on mitigating existing inequalities than on securing equal treatment, the delegates of the CSW were drawn to working within a conventional view of women as mothers. ${ }^{19}$ This approach came into sharp focus in the revised version of the UN Declaration of the Rights of the Child, which after nearly a decade of shelf-life made its way through the UN Commission on Human Rights to the UN General Assembly in the fall of 1959. One feature that distinguished this document from the 1924 Geneva Declaration was the several references to parents and especially mothers. The child, the declaration stated, "shall, wherever possible, grow up in the care and under the responsibility of his parents, and, in any case, in an atmosphere of affection and of moral and material security; a child of tender years shall not, save in exceptional circumstances, be separated from his mother." ${ }^{20}$ The declaration further announced that the child (consistently referred to as a "he"), "shall be entitled to grow and develop in health; to this end, special care and protection shall be provided both to him and to his mother, including adequate pre-natal and post-natal care." ${ }^{21}$ Thus, in keeping with the precedent set 
by the UDHR, the child rights declaration did not separate the rights of children from the rights and duties of motherhood.

There is limited research on the making of the 1959 child rights declaration and what prompted the rise of interest in children's rights during this period. One important reason why the needs of children came to the fore in this period was clearly the lack of progress in other areas of human rights. Since the early 1950s, the drafting of the main covenants on human rights had been stalled because of deepening Cold War tensions. Children's rights and women's rights were among the few areas where states nonetheless managed to find common ground. There were also other reasons. For instance, historian Zoe Moody notes how the archival records include frequent references to trends in development psychology, including a report that the influential attachment theorist John Bowlby penned for WHO in 1952 that stressed "maternal deprivation" in the child's earliest years as a key predictor of later "mental disturbances." 22

Such maternalist discourses on child development provided space for women's activism. In the fall of 1959, Paul Hofmann, The New York Times reporter to the United Nations, commented that the work to finalize the UN's "children's charter" had been spearheaded by "women delegates, many of them mothers." 23 The sessions of the Third Committee were chaired by the Belgian lawyer and liberal politician Georgette Ciselet, who had been one of Europe's most prominent champions of the rights of women and motherhood. In 1946, Ciselet had been the first woman elected into the Belgian parliament and had initiated progressive national legislation on marriage equality and the rights of children born out of wedlock. As part of the Belgian UN delegation, she had monitored the development of international standards on women's political rights and the registration of marriages, and had served as her country's representative to the CSW. ${ }^{24}$ While Ciselet helped to ensure that the child rights declaration was unanimously approved in the UN General Assembly, some delegates quibbled over aspects of the document's design. Zoya V. Mironova, the USSR ambassador and founding member of the Women's International Democratic Federation, lamented that the declaration lacked adequate mechanisms of enforcement and contained no reference to the rights of working mothers. The problem in Mironova's view was not that the document tied children's rights to the plights of mothers, but that it did not imagine women as active citizens and economic agents. ${ }^{25}$

\section{Gender and the UN convention on the rights of the Child}

In hindsight, what is most striking about the 1959 UN Declaration on the Rights of the Child was how quickly it became obsolete. Moody, who has studied the document's drafting and early reception, claims that within only a few years, the document had been virtually forgotten, including by international and nongovernmental bodies working in the fields of child welfare and child development. In light of the geopolitical, social, and cultural transformation of the 1960 s, the declaration seemed to be a statement of principles belonging to an increasingly distant postwar moment. ${ }^{26}$ This was not just because it reflected stereotyped ideas about motherhood and the division of domestic labor. The text 
was completed just before states of the Global South breathed new life into the international human rights project, effectively paving the way for the completion of the UN's core human rights covenants in 1966, documents which contained only scattered references to child protection again in the context of parental rights. ${ }^{27}$ While the language of children's rights still featured in international human rights resolutions of this era (e.g., in the final communiqué of the 1968 World Conference on Human Rights in Teheran), it was subordinated to the increasingly dominant causes of decolonization and non-discrimination. ${ }^{28}$ There was, as of yet, no talk of a binding treaty directly concerned with children's specific needs and interests.

In the 1970s, UN human rights politics took a structural turn. Influenced by the launch of the New International Economic Order, it became a field that was increasingly occupied with global economic inequalities and domestic patterns of racial and gender discrimination. ${ }^{29}$ At the same time, structural interpretations of human rights project were countered by other, predominantly Western, readings focusing on individual liberties and equality of opportunity. These differences came into full view during the World Conference for the International Women's Year in Mexico City in June 1975. While this served as a crucial event in forging new international alliances among women's rights activists and established the UN Decade for Women, it also revealed deep divides among feminists, including the conflict over the relationship between the struggle for equal human rights and economic justice. ${ }^{30}$

Some of these tensions were built into the 1979 UN Convention Against All Forms of Discrimination Against Women (CEDAW), which oscillated between an emphasis on liberation from stereotyped gender roles and protection within such roles. In some respects, then, the treaty was of direct relevance to the rights of children. More specifically, Article 5 on family education mentioned the need to promote awareness of "maternity as a social function" as well as the "common responsibility of men and women in the upbringing and development of their children," and suggested that such education must carry out with respect for the child's best interests. Article 16(2) addressed the question of child marriage, although it evaded the question of who counts as a child. ${ }^{31}$ Still, CEDAW was not a child rights treaty. As Cynthia Price-Cohen argues, its shape and content reflect how the international movement for women's human rights was principally occupied with correcting inequalities between adult men and women. It did not address the needs of the girl-child, effectively ignoring what Price-Cohen saw as the "importance of preparing girls to become women." 32

Still, the advances in women's rights and feminist theory were crucial for reviving the question of children's rights during this period. Some of the most outspoken proponents of the radical but short-lived movement for child liberation, like Richard Farsons and John Holt, sought to transfer some of the energy and arguments of the civil and women's rights movements to a project of challenging the ingrained assumptions of childhood. ${ }^{33}$ Partly inspired by the works of historian Phillippe Ariès, these child liberationists claimed that "childhood" was a recently innovated category, which served only to justify the adult oppression of young beings, and which therefore could and should be dismantled. ${ }^{34}$ In her 
influential 1970 pamphlet The Dialectics of Sex, Shulamith Firestone included a full chapter on childhood, where she claimed that discrimination on the basis of age was akin to that of gender, and that women had to "include the oppressio of children in any program for feminist revolution." ${ }^{35}$

The proponents of child liberation were met with strong suspicion, not just among conservatives who saw their views as an attack on family values, but also among child rights advocates, who maintained that they denied the natural vulnerabilities of young age. At the international level, the discourse of children's rights was still dominated by its ties to child protection. ${ }^{36}$

In the UN context, the protectionist view of children's rights was reinforced in the context of the International Year of the Child (1979). The initiative for a child year was first put forward by Canon Joseph Moerman, the International Catholic Child Bureau's representative in Geneva. Moerman was disheartened by the ideological battles that had dominated the recent international years on women (1975) and population (1976), and he suggested that the international community now needed to engage in a more reconciliatory project. In 1975, he began lobbying other non-governmental organizations and international agencies and eventually secured the backing of both UNICEF and UN Secretary General Kurt Waldheim. The basic condition set up by UNICEF Executive Director Henri Labouisse was that there would be no international conference like the one on women in Mexico, and that the year would be geared towards actions at the national level. The international side of things would mainly be about scaling up international aid to developing countries and boosting awareness of UNICEF's work in securing children's basic needs. Once the project had been scheduled for 1979, it was decided that it would also be labelled as a year for children's rights, since it would coincide with the twentieth anniversary of the 1959 Declaration. Nevertheless, the underlying premise of the International Year of the Child was that children's rights, unlike general human rights, was a non-political, non-disruptive concept that was principally about securing basic needs and protections from the worst forms of abuse and neglect. ${ }^{37}$

It was in this context that the Polish government unexpectedly tabled a draft Convention on the Rights of Child. This in and of itself was not a novel idea. Already in the 1950s, the Communist states had called for a binding international instrument that would emphasize the importance of national legislation and the effective use of state power in safeguarding children's rights to protection and welfare. The advent of a child year seemed like a fortuitous moment to give it another try. Besides, the Polish government was weary that "progress in legislation on the rights of the child should not lag behind that made in other spheres of international law. ${ }^{{ }^{38}}$ However, the Polish draft was not well received outside of the Warsaw Pact. The few states who cared to respond to the initial draft were unenthusiastic about the way it largely reproduced the content of the 1959 UN Declaration of the Rights of Child, merely changing its form into a binding treaty. The Netherlands and the Nordic countries pointed directly to the ways in which the draft failed to recognize the transformations in social values and the structures of modern welfare states that had taken place during the intervening decades; not only was there an increasing awareness of the dangers of child abuse, but 
the realities of working parents were also more apparent. Further, the text was criticized as flotsam from a pre-decolonization era in UN human rights politics. ${ }^{39}$

Though the Polish initiative led to the creation of a designated working group under the Commission on Human Rights, it was not until the mid-1980s that the project of completing the UN Convention on the Rights of the Child gained momentum. This was partly due to the changing global landscape with the rise of Gorbachev, which eased Cold War tensions, at least in Europe. Another key factor was the finalization of the UN Convention Against Torture, which freed up space and resources for UN delegations in Geneva. Significant in this process were the concerted efforts by non-governmental organizations who participated in the drafting process. Through the creation of a designated NGO group on the UN Convention on the Rights of the Child, these groups - spearheaded by Defense for Children International, the International Catholic Child Bureau, and the Swedish Save the Children - not only influenced those states partaking in the drafting process, but they also helped to convince an initially reluctant UNICEF to get on board with the idea of formulating a binding human rights treaty for children. $^{40}$

Some of the organizations that followed the drafting process from its earliest days were women's rights groups, including the International Federation of Women Lawyers and the Women's International Democratic Federation. Several of the most active NGO delegates were women, including Rachel Brett of the Quakers, Geraldine van Bueren of Amnesty International, and Cynthia PriceCohen of the Human Rights Internet. In the final stages of the drafting, some of these women helped to ensure that the child rights convention was the first international human rights treaty written in completely gender-neutral language. Whereas the 1959 Declaration had spoken of the rights-bearer as a "he," the convention either used the neutral "the child" or the combined pronoun "he or she." 41

Still, it would be an exaggeration to label the UN Convention on the Rights of the Child as a "feminist landmark." In her thorough analysis of this event, political scientist Anna Holzscheiter notes how the drafting process was characterized by a general lack of attention to issues of gender. It was generally assumed that childhood was a universal experience, and very little attention was paid to its intersection with other grounds of vulnerability and discrimination, such as class, race, and gender. Further, the term "girl-child" was absent in the text. Perhaps most striking was the fact that the convention did not include a reference to child marriage, like the one in CEDAW. This inattentiveness to gender, Holzscheiter argues, "seems all the more astonishing in view of the fact that several women's NGOs participated in the drafting," and that it "coincided with the International Decade for Women (1975-1985)." ${ }^{2}$ This lack of attention to gender equality also explains some reluctance that women's rights organization had in becoming involved in the project. The Portuguese delegate to the drafting process and would-be UN Special Representative Marta Santos-Pais claimed that some women's rights organizations saw it as "taking away the light from them and the focus they were receiving in the previous years." 43

A notable exception to the general lack of focus on gender was the discussion on harmful traditional practices, a phrase which was code for female 
genital mutilation. As is well-known, female genital mutilation was one of the main global issues around which feminists of different origins and orientations coalesced in the 1970s. While they often disagreed in their analysis of what it was - Western feminists like Fran Hosken thought of it as a cultural and religious practice, whereas southern feminists like Nawal el Saadawi framed it as but one of many instances indicative of a global patriarchal structure- they generally agreed on its detrimental effects on women. Still, the issue had not been addressed in CEDAW, and it remained highly uncertain as to where, if anywhere, in the landscape of international agencies and multilateral organizations it really belonged. Internationally, the concept of female genital mutilation was frequently linked to culture, religion and civilization, rather than patriarchy, which meant that it rekindled infected debates on Western moral imperialism, and aggravated North-South tensions between feminist activists. More still, many within the human rights community considered it as a matter that belonged to the private sphere and which therefore was beyond the reach of the emerging field of human rights law. ${ }^{44}$

In this context, the drafting of the UN Convention on the Rights of the Child was a significant step forward. At the back of Article 24 on the right to health, the convention calls on states to take "effective and appropriate measures with a view to abolishing traditional practices prejudicial to the health of children." 45 This was the first time that an international treaty labelled female genital mutilation as incompatible with human rights. One key to this development was that the talks on children's human rights were relatively open to interventions by non-governmental organizations and that many of these organizations were becoming increasingly committed to facilitating co-operation across NorthSouth divides. In the mid-1980s, the Inter-African Committee on Traditional Practices Affecting the Health of Women and Children (IAC) - represented by the Ethiopian rights activist Berhane Ras-Work - and the Swedish Save the Children successfully lobbied Senegal to demand a UN report on female genital mutilation. The report, which appeared in 1986 and was penned by the Moroccan diplomat Halima Embareck Warzazi, helped to legitimate discussion on the topic in the UN Commission of Human Rights and to defuse charges of moral imperialism. In 1987, the Swedish Save the Children, acting on behalf of a wider group on NGOs tabled a draft article that became the basis the for the final version of the Convention's Article 24(3). ${ }^{46}$ As this clause was unanimously approved, it helped to define female genital mutilation and other forms severe abuse of children in private spaces, as legitimate targets of human rights law and politics. ${ }^{47}$

\section{Concluding reflections}

The UN Convention on the Rights of the Child was not launched as a project aimed at challenging gender relations. Instead, the treaty grew out of the International Year of the Child of 1979, an event which had partly been launched to counterbalance the contentious international debates on gender equality that had taken place in the second half of the 1970s. Moreover, the convention's drafting 
unfolded with little attention to the intersections of age and gender. The point of concern was not that gender was too sensitive a topic to influence the convention. Rather, as Holzscheiter puts it, "gender did not even emerge as an issue in its own right," and if it did, it was generally neutralized in reference to the convention's general clause on non-discrimination. ${ }^{48}$ The text reiterated some provisions of earlier international instruments on human rights and children's rights that highlighted the importance of the nuclear family in the child's physical, mental, and emotional development. It further contained a preambular clause on the child's rights to protection, both before as well as after birth, thus raising doubts about the treaty's compatibility with the right to abortion. It was, in short, a convention that affirmed rather than challenged many of the conservative elements in international human rights discourse.

Still, as this chapter has shown, some women diplomats and activists found ways of using the drafting of the UN Convention on the Rights of the Child to address issues that were of strong significance to the rights of girls, including female genital mutilation and domestic violence. While the convention's language was imprecise and open to all kinds of interpretation, it helped pave the way for a more radical transformation of human rights politics that would take place in the 1990s, especially during the Vienna Conference on Human Rights $1993^{49}$ and the Beijing Conference of $1995,{ }^{50}$ where the rights of women and girls emerged as central topics of concern.

These events, and especially the Vienna Conference, are now best remembered for the slogan that "women's rights are human rights." ${ }^{51}$ Still, what changed in this period was not strictly the understanding of to whom human rights applied. As many of the contributions to this volume show, women's rights, much like children's rights, had been part of the international human rights discourse since its inception. Rather, the transformation was mainly about where human rights norms were of relevance. ${ }^{52}$ The developments in the 1990s struck a decisive blow to the public-private distinction in international human rights law and politics, affirming that the right to privacy is no justification for gender violence. These transformations were partly carried forward by the gains made in the UN Convention on the Rights of the Child. While this text did not emerge as a feminist treaty, some of its clauses, and especially the provisions on harmful traditional practices, became a means of casting violations of girls and women in the private sphere as affronts to their fundamental human rights and dignity.

In a broader sense, the history of children's rights reminds us of the difficulties in writing about women's agency in UN human rights politics. There is always the danger that we may be highlighting only those examples in which women were championing what we now, with the benefit of hindsight, consider as progressive projects and ideals. It is also easy to overlook that the women who participated in these processes, for the most part, were loyal representatives of their respective governments and host-organizations with limited possibility to influence policy. It is therefore worth noting how the codification of romanticized ideas of motherhood in, for instance, the 1959 UN Declaration of the Rights of the Child was spearheaded by women delegates. Also, the strong presence of women diplomats and activists in the drafting of the UN Convention on the Rights of the Child did 
not ensure that this treaty was crafted with special attention to the structures of gender inequalities. For the history of women's activism in the context of UN human rights politics to be a source of deepened understanding, such tensions, including those among feminists, must not be bracketed; instead, they should be framed into central objects of study.

\section{Notes}

1 See, for instance, the Universal Declaration of Human Rights (1948), Article 25; International Covenant on Economic, Social and Cultural Rights (1966), Article 10.

2 Frances Olsen, "Children's Rights: Some Feminist Approaches to the United Nations Convention on the Rights of the Child," International Journal of Law, Policy and the Family 6 no. 1 (1992): 192.

3 It should be noted that this chapter forms part of a much bigger undertaking of charting the history of children's rights in international politics. Thus, my general concern here lies not with the histories of female activism or women's rights, histories which are better told by others (e.g., see Valgerður Pálmádottir, "Perplexities of the Personal and the Political: How Women's Liberation became Women's Human Rights" (PhD diss., Umeå University, 2018). Instead, I am mainly interested in challenging an established and overtly linear narrative portraying the UN Convention on the Rights of the Child (1989) as a natural endpoint of moral development that was spurred by a growing appreciation of children as individual human beings. In response, I want to sketch an account that brings to light the situational and often-times conflicting uses of children's rights at the international level, an account that is attentive to the "mélange of contradictory intentions, moral dilemmas and divergent interpretations of the term itself," as human rights historian Jan Eckel puts it in The Ambivalence of Good: Human Rights in International Politics Since the 1940s (New York: Oxford University Press, 2019), 340.

4 Helen Swanwick of the Women's International League for Peace and Freedom, cited in Linda Mahood, Feminism and Voluntary Action: Eglantyne Jebb and Save the Children, 1876-1928 (Basingstoke: Palgrave Macmillan, 2009), 190.

5 Bruno Cabanes, The Great War and the Origins of Humanitarianism, 1918-1924 (New York: Cambridge University Press, 2015), 296.

6 For a notable exception pointing to the lack of discussions on gender, see Anna Holzscheiter, Children's Rights in International Politics: The Transformative Power of Discourse (Basingstoke: Palgrave Macmillan, 2010), 229-231.

7 Cited in Zoe Moody, "The United Nations Declaration of the Rights of the Child (1959): Genesis, Transformation and Dissemination of a Treaty (Re)constituting a Transnational Cause," Prospects 45 no. 1 (2015): 19.

8 The Universal Declaration of Human Rights (1948), Article 25(2).

9 UN Doc. E/CN.4/AC.2/SR.6 (1947), 2. For more on Begtrup see Kristine Midtgaard, "Bodil Begtrup and the Universal Declaration of Human Rights: Individual Agency, Transnationalism and Intergovernmentalism in early UN Human Rights," Scandinavian Journal of History 36 no. 4 (2011): 479-499.

10 UN Doc. A/C.3/SR.145 (1948), 576.

11 UN Doc. A/C.3/SR.143 (1948), 555.

12 UN Doc. A/C.3/SR.144 (1948), 570.

13 The French delegate René Cassin stated that while "he had voted in favour of according social protection to illegitimate children, he had not been able to vote for granting them equal civil rights." UN Doc. A/C.3/SR.146 (1948), 579.

14 Nancy Fraser, Fortunes of Feminism: From State Managed Capitalism to Neoliberal Crisis (London: Verso, 2017), ${ }^{197}$.

15 Jessica Whyte, The Morals of the Market: Human Rights and the Rise of Neoliberalism (London: Verso, 2019), 94-95. 
16 Allida Black, “Are Women 'Human'? The UN and the Struggle to Recognize Women's Rights as Human Rights," in The Human Rights Revolution: An International History, ed. Akira Iriye, Petra Goedde and William I. Hitchcock (New York: Oxford University Press, 2012), 141.

17 Devkai Jain, Women, Development, and the UN: A Sixty-Year Quest for Equality and Justice (Bloomington: Indiana University Press, 2005), 22.

18 ILO Maternity Protection Convention (Revised), 1952 (No. 103).

19 Jain, Women, Development, and the UN, 22.

20 UN General Assembly Resolution 1386(XIV) of 20 November 1959.

21 UN General Assembly Resolution 1386(XIV) of 20 November 1959, Principles 4 and 6.

22 Zoe Moody, Les droits de l'enfant: genèse, institutionnalisation et diffusion, 19241989 (Neuchâtel: Éditions Alphil), 190-191; John Bowlby, Maternal Care and Mental Health (Geneva: World Health Organisation, 1952), 13.

23 Paul Hoffmann, "UN Body Backs Child Charter," New York Times, October 20, 1959.

24 Catherine Jacques, "Georgette Ciselet," in Dictionnaire des femmes belges: XIXe et XXe siècles, ed. Éliane Gubin, Catherine Jacques, Valérie Piette and Jean Puissant (Brussels: Éditions Racine, 2006), 100-103.

25 Hoffmann, "UN Body Backs Child Charter."

26 Moody, "The United Nations Declaration of the Rights of the Child (1959)," 24.

27 See, .e.g., CESCR, arts. 10 and 13; CCPR, arts. 18, 24. For more on the context of decolonization, see Steven L. B. Jensen, The Making of International Human Rights (New York: Cambridge University Press, 2016).

28 "The Proclamation of Teheran" (1968), in Final Act of the International Conference on Human Rights, April 22-May 13, 1968, UN Doc. A/Conf.32/41 (1968), p. 4, art. 14.

29 Julia Dehm, "Highlighting Inequalities in the Histories of Human Rights: Contestation over Justice, Needs and Rights in the 1970s," Leiden Journal of International Law 31 no. 4 (2018): 871-895.

30 Roland Burke, "Competing for the Last Utopia? The NIEO, Human Rights, and the World Conference for the International Women's Year, Mexico City, June 1975," Humanity Journal 6 no. 1 (2015): 47-61.

31 Convention on the Elimination of All Forms of Discrimination against Women New York (1979).

32 Cynthia Price-Cohen, "The United Nations Convention of the Rights of the Child: A Feminist Landmark," William \& Mary Journal of Race, Gender, and Social Justice 3 no. 1 (1997): 36-40.

33 Jean Fortin, Children's Rights and the Developing Law, 3rd ed. (New York: Cambridge University Press, 2009), 5-7.

34 Phillippe Ariès, Centuries of Childhood (Pimlico, London, 1996).

35 Shulamith Firestone, The Dialectic of Sex: The Case for Feminist Revolution (New York: Morrow, 1970), 104.

36 Michael D. A. Freeman, "The Rights of Children in the International Year of the Child," Current Legal Problems 30 no. 1 (1980): 30.

37 This summarizes Linde Lindkvist, "1979: A Year of the Child, but Not of Children's Human Rights," Diplomatica 1 no. 2 (2019): 202-220.

38 UN Doc. E/CN.4/SR.1438 (1978), 10.

39 See comments by Netherlands and Sweden in UN Doc. E/CN.4/1324 (1978), w.

40 Cynthia Price Cohen, "The United Nations Convention on the Rights of the Child: Involvement of Nongovernmental Organizations" (Conference presentation, The United Nations in a Changing World: Looking to the Next Half-Century, Academic Council of the United Nations System, New York, June 19-21, 1995), in Papers of Canon Joseph Moerman, Box 5, Folder 10.

41 Cynthia Price-Cohen, "The United Nations Convention of the Rights of the Child: A Feminist Landmark," William \& Mary Journal of Race, Gender, and Social Justice 3 no. 1 (1997): 47.

42 Holzscheiter, Children's Rights in International Politics, 230. 
43 Cited in Ibid., 230.

44 Kelly J. Shannon, "The Right to Bodily Integrity. Women's Rights as Human Rights and the International Movement to End Female Genital Mutilation, 1970s-1990s," in Akira Iriye, Petra Goedde, and William I. Hitchcock (eds.) The Human Rights Revolution (New York: Oxford University Press, 2012),285-310. See also Devkai Jain, Women, Development, and the UN: A Sixty-Year Quest for Equality and Justice (Bloomington: Indiana University Press, 2005), 28.

45 UN Convention on the Rights of the Child (1989), Article 24.3.

46 UN Doc. E/CN.4/1987/25 (1987), para. 28.

47 Simone Ek, Självklart barnets rättigheter (Stockholm: Rädda Barnen, 2009).

48 Holzscheiter, Children's Rights in International Politics, 231.

49 Declaration on the Elimination of Violence against Women, 20 December 1993, UN Doc. A/RES/48/104 (1994).

50 Beijing Declaration and Platform for Action (1995), which was one of the first documents to provide a sustained treatment of girls' human rights.

51 Charlotte Bunch and Roxanna Carrillo, "Women's Rights are Human Rights: A Concept in the Making," in Women and Girls Rising: Progress and Resistance Around the World, ed. Ellen Chesler and Terry McGovern (London, Routledge, 2016), 32-49.

52 Dorothea Anthony, "The World Conference on Human Rights: Still a Guiding Light a Quarter of a Century Later," Australian Journal of Human Rights 25 no. 3 (2019): 411-417.

\section{Bibliography}

Anthony, Dorothea. "The World Conference on Human Rights: Still a Guiding Light a Quarter of a Century Later." Australian Journal of Human Rights 25 no. 3 (2019): 411-427.

Ariès, Phillippe. Centuries of Childhood, New Edition. London: Pimlico, 1996.

Black, Allida. "Are Women 'Human'? The UN and the Struggle to Recognize Women's Rights as Human Rights." In The Human Rights Revolution: An International History, ed. Akira Iriye, Petra Goedde and William I. Hitchcock. New York: Oxford University Press, 2012: 133-158.

Bowlby, John. Maternal Care and Mental Health. Geneva: World Health Organisation, 1952.

Bunch, Charlotte and Carrillo, Roxanna. "Women's Rights are Human Rights: A Concept in the Making."'In Women and Girls Rising: Progress and Resistance Around the World, ed. Ellen Chesler and Terry McGovern. London: Routledge, 2016, 32-49.

Burke, Roland. "Competing for the Last Utopia? The NIEO, Human Rights, and the World Conference for the International Women's Year, Mexico City, June 1975." Humanity Journal 6 no. 1 (2015): 47-61.

Cabanes, Bruno. The Great War and the Origins of Humanitarianism, 1918-1924. New York: Cambridge University Press, 2015.

Dehm, Julia. "Highlighting Inequalities in the Histories of Human Rights: Contestation over Justice, Needs and Rights in the 1970s." Leiden Journal of International Law 31 no. 4 (2018): 871-895.

Eckel, Jan The Ambivalence of Good: Human Rights in International Politics Since the 1940s. New York: Oxford University Press, 2019.

Ek, Simone. Självklart barnets rättigheter. Stockholm: Rädda Barnen, 2009.

Firestone, Shulamith. The Dialectic of Sex: The. Case for Feminist Revolution. New York: Morrow, 1970. 
Fraser, Nancy. Fortunes of Feminism: From State Managed Capitalism to Neoliberal Crisis. London: Verso, 2017.

Freeman, Michael D. A. "The Rights of Children in the International Year of the Child." Current Legal Problems 30 no. 1 (1980): 1-31.

Fortin, Jean. Children's Rights and the Developing Law, 3rd ed. New York: Cambridge University Press, 2009.

Holzscheiter, Anna. Children's Rights in International Politics: The Transformative Power of Discourse. Basingstoke: Palgrave Macmillan, 2010.

Jacques, Catherine. "Georgette Ciselet.” In Dictionnaire des femmes belges: XIXe et XXe siècles, ed. Éliane Gubin, Catherine Jacques, Valérie Piette and Jean Puissant. Brussels: Éditions Racine, 2006: 100-103.

Jain, Devkai. Women, Development, and the UN: A Sixty-Year Quest for Equality and Justice. Bloomington: Indiana University Press, 2005.

Jensen, Steven L. B. The Making of International Human Rights. New York: Cambridge University Press, 2016.

Lindkvist, Linde. "1979: A Year of the Child, but Not of Children's Human Rights." Diplomatica 1 no. 2 (2019): 202-220.

Mahood, Linda. Feminism and Voluntary Action: Eglantyne Jebb and Save the Children, 1876-1928. Basingstoke: Palgrave Macmillan, 2009.

Midtgaard, Kristine."Bodil Begtrup and the Universal Declaration of Human Rights: Individual Agency, Transnationalism and Intergovernmentalism in early UN Human Rights." Scandinavian Journal of History 36 no. 4 (2011): 479-499.

Moody, Zoe. "The United Nations Declaration of the Rights of the Child (1959): Genesis, Transformation and Dissemination of a Treaty (Re)constituting a Transnational Cause," Prospects 45 no. 1 (2015): 15-29.

Moody, Zoe Les droits de l'enfant : Genèse, Institutionnalisation et Diffusion, 1924-1989. Neuchâtel: Éditions Alphil.

Olsen, Frances. "Children's Rights: Some Feminist Approaches to the United Nations Convention on the Rights of the Child." International Journal of Law, Policy and the Family 6 no. 1 (1992): 192-220.

Pálmádottir, Valgerður. "Perplexities of the Personal and the Political: How Women's Liberation became Women's Human Rights.” PhD diss., Umeå University, 2018.

Price-Cohen, Cynthia. "The United Nations Convention of the Rights of the Child: A Feminist Landmark." William \& Mary Journal of Race, Gender, and Social Justice 3 no. 1 (1997): 29-78.

Shannon, Kelly J. "The Right to Bodily Integrity. Women's Rights as Human Rights and the International Movement to End Female Genital Mutilation, 1970s-1990s." In The Human Rights Revolution: An International History, ed. Akira Iriye, Petra Goedde and William I. Hitchcock. New York: Oxford University Press, 2012: 285-310.

Whyte, Jessica. The Morals of the Market: Human Rights and the Rise of Neoliberalism. London: Verso, 2019. 